\title{
Mestizo Farmers' Knowledge of Entomofauna Is Reflected in Their Management Practices: A Case Study in the Andean-Amazon Foothills of Peru
}

\author{
Lucila Marcela Beltrán-Tolosa ${ }^{1,2 *}$, Gisella S. Cruz-Garcia ${ }^{1,3}$, Reynaldo Solis ${ }^{4}$ and \\ Marcela Quintero ${ }^{1}$ \\ ${ }^{1}$ International Center for Tropical Agriculture, Cali, Colombia, ${ }^{2}$ Universidad Nacional de Colombia, Palmira, Colombia, \\ ${ }^{3}$ Oxfam Novib, The Hague, Netherlands, ${ }^{4}$ Instituto de Investigaciones de la Amazonía Peruana (IIAP), lquitos, Peru
}

\section{OPEN ACCESS}

Edited by: Helda Morales,

The South Border College (ECOSUR), Mexico

Reviewed by:

Jeffery W. Bentley,

Cornell University, United States

Elda Miriam Aldasoro Maya, National Council of Science and Technology (CONACYT), Mexico

*Correspondence:

Lucila Marcela Beltrán-Tolosa lumbeltranto@unal.edu.co

Specialty section:

This article was submitted to Agroecology and Ecosystem Services, a section of the journal Frontiers in Sustainable Food Systems

Received: 02 March 2020

Accepted: 12 August 2020

Published: 19 October 2020

Citation:

Beltrán-Tolosa LM, Cruz-Garcia GS, Solis R and Quintero M (2020) Mestizo Farmers' Knowledge of Entomofauna Is Reflected in Their Management

Practices: A Case Study in the Andean-Amazon Foothills of Peru. Front. Sustain. Food Syst. 4:539611. doi: 10.3389/fsufs.2020.539611
Local knowledge of entomofauna can influence environmental actions, particularly crop management practices, which can be sustainable or unsustainable. A farmer's decision-making is associated with their knowledge of beneficial insects and pests. This study aimed to assess local knowledge of entomofauna in relation to associated management practices, within a context of socio-cultural and environmental change. The research was carried out in Santa Lucía, a small mestizo village located in the deforestation frontier of the Peruvian Amazon. Mestizos are migrants, or descendants of migrants, from non-Amazonian regions of Peru. First, freelistings were conducted with a group of 19 female and 25 male farmers to evaluate their theoretical knowledge of insects, and to select the most salient insects associated with cassava, maize, and plantain. Second, two focus groups (which separated women and men) evaluated the practical knowledge of management practices for the most salient insects in the context of climate change. The most salient insects were collected and identified to the minimum possible taxonomic level. The results showed that farmers have a negative perception of entomofauna associated with cassava, maize, and plantain, as they considered insects to be harmful to their staple crops. Most farmers are not aware of the importance of beneficial insects such as pollinators and natural enemies. The findings of the study further showed that mestizo farmers did not have any management practices to preserve beneficial entomofauna, half of the insects they regarded as pests did not present any associated management practices, and the other half applied both sustainable (preventive and curative) and unsustainable practices (e.g., use of pesticides). The paper further discusses the dynamics of mestizo local knowledge on entomofauna in a changing environment and concludes that local capacities should be built to enrich knowledge about the recognition, biology, and ecological role of entomofauna (e.g., pollination, natural predation), and associated management practices (e.g., agroecological preventive practices that decrease pest incidence and protect pollinators, instead of curative practices) as an adaptation strategy to climate change.

Keywords: local knowledge, agroecological practices, beneficial insects, pests, climate change 


\section{INTRODUCTION}

Local knowledge (LK) is defined as "A cumulative body of knowledge, practice, and belief, evolving by adaptive processes and handed down through generations by cultural transmission, about the relationship of living beings (including humans) with one another and with their environment" (Berkes, 1999). LK is linked to the necessity of interacting, using, and managing local ecosystems and has a holistic approach that includes beliefs, a system of knowledge or theory (theoretical knowledge), and a group of practices (practical knowledge). Farming communities build images from nature based on their beliefs and establish interpretations of their environment by observing elements, facts, and patterns. They tend to recognize and name elements that are not only easily observed, but also culturally important for both utility or harm (Bentley and Rodríguez, 2001). Then, based on their cognition and interpretation they decide on and carry out practices to manage the environment. LK is acquired through trial and error in processes of learning and experimentation (Price, 2001). It is accumulated, transmitted, and modified through generations, and mediated by gender (Toledo et al., 1992; Toledo, 2002; Barrera-Bassols and Toledo, 2005; Sunderland et al., 2014).

LK influences environmental actions (Price, 2001), particularly management practices, which could be environmentally friendly (e.g., agroecological practices) or, unsustainable. Agroecological practices contribute to sustainable crop production by promoting farm diversification and the use and conservation of natural resources (Altieri, 2002; Wetzel et al., 2013). These practices increase the adaptive capacity of agroecosystems, making farmers less vulnerable to climate extreme events (Altieri et al., 2015). For example, these practices promote pest management through natural enemies, biopesticides, or management practices that protect beneficial biota, such as soil organisms and pollinators, contributing to soil fertility, and crop production. Unsustainable conventional practices promote the excessive use of chemical pesticides to control pests, which not only decrease the population of beneficial organisms but also contaminate the environment, negatively affecting rural households whose livelihoods depend on multiple ecosystem services. For example, recent studies have demonstrated that one of the main causes of the decline of beneficial entomofauna is the use of synthetic pesticides (Sánchez-Bayo and Wyckhuys, 2019). In addition, climate change is also contributing to this decline. For example, the changes in temperature and precipitation patterns caused by climate change might cause shifts in flowering seasons that affect the continuous availability of pollen throughout the foraging season of bees (van der Sluijs and Vaage, 2016). Moreover, floods, caused by climate change, are likely to be risky to bee species that nest or hibernate underground (Goulson et al., 2015). The negative effects of synthetic pesticides on pollinator populations might be exacerbated by climate change, decreasing crop production, and affecting human food security (van der Sluijs and Vaage, 2016).

Farmers who understand the ecological function of beneficial insects are less likely to have unsustainable management practices associated with entomofauna (Price, 2001; Wyckhuys and O'Neil, 2007). For example, based on the knowledge that ants and social wasps are natural enemies of pests, farmers in Honduras invented sugar-watery sprays to attract these insects (Wyckhuys and O’Neil, 2007). Maya farmers in Patzún, Guatemala, are familiar with insects associated with milpa (intercrop of corn, beans, and other edible plants). While they recognize all insects identified as pests by scientists, they do not consider them to be pests, arguing that all animals have a function in nature. Thus, they do not use any curative methods to manage insects, but their agricultural management methods (site selection, terrain preparation, and timing of planting) act as preventive methods that manage pests, resulting in a low incidence of pests in their milpas (Morales and Perfecto, 2000). Price (2001), and Price and Gurung (2006) mentioned that it is important to enhance the environmental knowledge of farmers to improve pest management behavior and sustainable management practices.

Conversely, a lack of knowledge about the ecological importance of insects makes farmers more likely to use unsustainable practices to manage pests (Wyckhuys and O'Neil, 2007; Midega et al., 2012; Wyckhuys et al., 2019). For example, López De La Cruz et al. (2018) found that limited knowledge about natural enemies of milpa pests and their life cycles in Maya farmers from Chiapas, Mexico, could impede farmers from employing biological control of insect pests. Munyuli (2011) also reported that $90 \%$ of farmers in a banana-coffee system of the Lake Victoria Arc in central Uganda were not aware of the role played by pollinators in the plantations, which was reflected in the excessive use of pesticides. Kasina et al. (2009) have documented that even beekeepers are likely to adopt pesticides to repel aggressive bees due to poor knowledge of their pollination service. Likewise, Gurung (2003) has explained that negative local beliefs associated with certain insects that have valuable roles in the agroecosystem (e.g., praying mantises pull out people's eyes and earwigs enter people's ears), might encourage the use of pesticides in Nepal. Thus, ecological literacy among farmers is key in determining the type of management practices that they use to manage insects (Wyckhuys et al., 2019).

Rural communities in the Andean-Amazon foothills (AAF) of Peru, which is one of the richest biodiversity eco-regions on Earth (Dinerstein et al., 2017), mainly depends on smallholder agriculture for their subsistence. The major staple crops in the AAF are cassava, maize, and plantain. These crops play a key role in the food security of the region, where they are not only central to the diet of local people but also constitute a source of income, particularly for poor farmers (Huamán Espino and Valladares, 2006; Ortiz et al., 2013; Molina Recio et al., 2016). However, climate change could cause an increase in temperatures in the AAF (Beltrán-Tolosa et al., 2020), which could affect the metabolic rate of pest insects, increasing their consumption of food and their population growth rates (Deutsch et al., 2018). As a result, crop damage would intensify, decreasing the production of key staple crops and exacerbating food insecurity in the AAF. In addition, the region is going through rapid processes of socio-cultural and environmental change, which are reflected in the expansion of the agricultural frontier, increased cash crop production, and deforestation (Finer et al., 2018). In this 
context, the use of agroecological adaptation strategies to manage entomofauna is necessary to strengthen local efforts to face climate change.

Understanding LK of both beneficial insects and pests, and their associated management practices, might provide insights for the design of agroecological management strategies of entomofauna aimed at decreasing the impact of climate change on crop production. This would ultimately contribute to improved food security and environmental conservation. This is certainly necessary for the AAF, where major processes of migration have been occurring in recent decades, alongside an increase of unsustainable agricultural practices (Murad and Pearse, 2018) and the vulnerability of farms to climate change. The hypothesis underlying this study is that smallholder farmers distinguish pests over beneficial insects associated with cassava, maize, and plantain (theoretical knowledge), and this is reflected in their practical knowledge (i.e., the absence of sustainable practices to protect beneficial entomofauna and reduce the incidence of pests). The research is based on a case study conducted in Santa Lucía, a small largely mestizo village in Yurimaguas, located in the AAF of Peru. Mestizos are migrants, or descendent from migrants, from nonAmazonian regions of Peru, and usually of mixed Indigenous and European heritage. Mestizos in Yurimaguas arrived since the 1960s from other provinces of the Peruvian Amazon and in the last 10 years from the highlands of the country. This study aims to assess LK about entomofauna associated with major staple crops in relation to their associated management practices, in the context of socio-cultural and environmental change.

LK was assessed from an ethnobiological approach. Ethnobiology studies how an ethnic, linguistic, or cultural group of people classify and organize their knowledge about the environment (Price, 2001). In this way, the study of LK was based on an emic approach, which refers to the understanding of local people's categorizations and classifications of the cultural domain or subject of interest (i.e., insects) that is based on the way they perceive the world using their language (in contrast to the etic approach, which is related to the researcher's categorization and classification of the object of study) (Martin, 2004). The study also has a gendered approach, given that gender affects LK, management, use, and access to environmental resources (Westermann et al., 2005; Dovie et al., 2008; Sunderland et al., 2014).

\section{STUDY SITE}

The research was conducted in the village of Santa Lucía, which is located at $180 \mathrm{~m}$.asl. and $22 \mathrm{~km}$ from the main city of Yurimaguas, situated along the Paranapura River, in the Yurimaguas district, Alto Amazonas province, Loreto region, Peru. Santa Lucía is in the forest-agriculture interface, possessing forested areas alongside agricultural fields. Previous studies have identified a loss of 34,012 ha of forest in Yurimaguas from 2004 to March 2017 with an annual loss rate of 2,557 ha/year since 2016 (Terra-i, 2017). The main causes of deforestation are the introduction of annual and perennial crops such as palm oil, rice, and papaya (Terra-i, 2017; Finer et al., 2018) The annual average rainfall in Yurimaguas fluctuates from 2,200 mm, and the average annual temperature oscillates between 22 and $26^{\circ} \mathrm{C}$. The rainy season takes place from December to March when the river water level rises, generating floods that affect local subsistence activities. It has been projected that the temperature will increase $2.2^{\circ} \mathrm{C}$ by 2050 and $4.2^{\circ} \mathrm{C}$ by 2080 , and that precipitation will increase $89 \mathrm{~mm}$ by 2050 and $350 \mathrm{~mm}$ by 2080 in the business as usual scenario (RCP 8.5), compared to the average temperature and precipitation from 1981 to 2010 (Beltrán-Tolosa et al., 2020). Farmers from Santa Lucía have already reported changes in climate patterns during a previous participatory rural appraisal conducted in the community (Beltrán-Tolosa et al., 2016). For instance, they argued that rainfall and temperatures have increased in the last 5 years, detrimentally affecting crop yields and increasing pests.

Santa Lucía has 64 families (460 inhabitants), and 90\% of them are mestizos. This study was conducted with mestizos. Before the 1960s Santa Lucía was a territory occupied by the indigenous Shawi people. After the 1960s, a first wave of migrants from different regions of Loreto settled in this territory, founding the village of Santa Lucía in March 1962. In 2009, there was a second wave of migration after the construction of a road, which connects Yurimaguas with Tarapoto. The population of Santa Lucía is mainly employed in subsistence farming growing cassava, maize, beans, and plantain for self-consumption and income generation, and the production of rice and cacao for income generation [Autoridad Nacional del Agua (ANA) del Peru, 2018]. They also depend on fishing and hunting to complement their diet.

The results of a household survey conducted in 2016 by the "Sustainable Amazonian Landscapes" project, which included a representative sample of 417 households in 35 settlements of Yurimaguas (including 20 households from Santa Lucía), indicated that the population is composed of $54 \%$ men and $46 \%$ women. The mean household size was four persons, with $93 \%$ of the households being male-headed. The women heading the remaining $7 \%$ of households were mainly divorcees or widows. Two percentage of men and 3\% of women older than 15 years were illiterate. Families cultivated an average area of 15 ha and reported a low number of agroecological practices for crop management (a mean of 1.5 out of 10 practices evaluated) (see note at the end of the paragraph). Some (22\% households, only three from Santa Lucía) participated in training on the implementation of silvopastoral and agroforestal systems, and agroecological practices, including soil management during 2015-2016 (Quintero et al., 2019). Most of the local inhabitants from Santa Lucía do not have access to sanitation services, electricity, and running water; their houses are built from wood with floors made of sand, and the main road is not paved (Beltrán-Tolosa et al., 2016).

Note: The agroecological practices evaluated were: crop rotation, intercropping, no slash and burn, cover crops, organic fertilizers, natural weed control, natural pesticides, no tillage, fallow lands, and lime application. The practices carried out were natural pesticides and no tillage. 


\section{METHODS}

\section{Methods of Data Collection}

Data collection took place in October 2017 in the mestizo village Santa Lucía, as part of the 4-year "Sustainable Amazonian Landscapes" project. Through the ongoing research project, one of the authors (RS) from the Instituto de Investigaciones de la Amazonía Peruana (IIAP) built a rapport with the local population, which facilitated approaching them for the assessment of LK. Village authorities were informed and consulted for approval before conducting the study. All persons who participated in the study did so freely and with prior informed consent.

To assess theoretical LK, first, the cultural domain, defined as the "set of items that are all of the same type" (Borgatti, 1998), was evaluated for the type "insect." For that, a group of 19 female and 25 male farmers were selected randomly from the village and asked to write on a piece of paper what they understand by the term "insect." Second, written freelistings, where informants are asked to elicit the different items that are part of a cultural domain, were conducted to assess the components of the cultural domain "insect" in relation to the main crops in the village and to identify which insects are the most cognitive salient ones (according to the cognitive salience index or CSI, explained in the data analysis sub-section). The freelistings were the first step in the ethnobiological analysis and were applied to uncover a cultural domain (Gatewood, 1984; Borgatti, 1998), and insect naming was the main indicator of theoretical LK (Gurung, 2003; Price and Gurung, 2006). In this exercise, informants were asked to write down all insects associated with cassava, maize, and plantain, with $10 \mathrm{~min}$ to write down the insects associated with each crop. It was explained to informants that they could include in their lists beneficial insects and/or pests. The insect names that people provided were recorded in the order they were given.

Practical LK was assessed through focus group discussions. Two separate focus groups (each composed of five women and five men) were carried out to capture the relations of the elicited insects and their respective crops, the management practices associated with beneficial insects and pests, and the perceived effects of climate change on the entomofauna. Participants were selected from the farmers who participated in the freelisting exercise based on their knowledge and willingness to participate in the focus group discussions. Focus groups took place 3 days after the free-listings (during these 3 days free-listings were analyzed and the lists of all elicited insects were prepared, as explained in the sub-section on data analysis). In the focus group discussions, participants were first shown the list of the most cognitively salient insects (highest CSI) per crop and asked if they agreed with or would like to add to the list. Second, informants were asked to discuss the following for each insect associated with each crop: (1) the relationship with the crop (i.e., if it is a beneficial insect or pest) and (2) the type of associated management practices (i.e., practices aiming at enhancing, tolerating or controlling the insect population). Third, to understand how farmers perceived the effects of climate change on entomofauna (which could partly explain the management practices they apply), they were asked if they think the climate has changed in the last 5 years and how, highlighting the indicators of climate change that caused more severe effects in agriculture; followed by the explanation of the effect of each indicator on each insect associated with cassava, maize, and plantain.

The taxonomical identification of the most cognitively salient insects was conducted after collection visits to cassava, maize, and plantain plantations in Santa Lucía. The visits were guided by a local informant (a focus group participant recognized as knowledgeable on entomofauna by villagers) who helped to search for the specimens. Insects were collected and preserved in ethanol 95\% and identified to the minimum taxonomic possible level (following Borror and De Long, 1988), with the collaboration of the IIAP. The collected insects were deposited in the Laboratory of Phytopathology of the IIAP, located in San Martín, Peru.

\section{Methods of Data Analysis}

Emic definitions of insects were analyzed by frequency of mention. Data from free listings were analyzed by combining both frequencies of mention and mean position of an insect across lists as part of the CSI index (Sutrop, 2001), separately for men's and women's lists per crop. The CSI was calculated as follows:

$\mathrm{CSI}=\mathrm{F} /(\mathrm{N} \mathrm{mP})$

$\mathrm{F}=$ Frequency of mention (number of lists in which the insect is named)

$\mathrm{N}=$ Total number of participants (number of lists)

$\mathrm{mP}=\left(\sum \mathrm{Rj}\right) / \mathrm{F}$ (Mean position of the term across participants' list)

$\mathrm{Rj}=$ Range of the term in an individual list.

The CSI assumed that the items (i.e., insects) more frequently mentioned and named first across informant lists are more salient or prominent than those named at the end. Scores can range from 0 to 1 , where 1 is the most salient insect, and 0 is the least salient insect. Most salient insects were defined as those with a CSI of 0.05 or higher. In addition, the mean length of lists was calculated for each crop (separately for men and for women), and a Mann-Whitney $U$-test for non-parametric data was used to test the statistical significance of the differences between men's and women's list lengths per crop, using the software R (R Studio Team, 2015).

Finally, the results of the focus groups were transcribed and presented in tables, separately for men and women.

\section{Methodological Limitations}

The methodology used has several limitations. First, the study did not include the local classifications of entomofauna, given that local people might classify insects under criteria other than associating them to specific crops; such assessment could have provided additional insights for the interpretation of the study results. Asking people for insects related to certain crops might have circumscribed people's comprehension of entomofauna, which is a wider universe than one of the insects associated with crops. Second, the way the question was asked in the freelisting exercise (i.e., which insects are associated to specific crops) could have caused participants to not consider other species beyond the 
TABLE 1 | Frequency of farmers' emic conceptualizations of entomofauna.

\begin{tabular}{|c|c|c|c|c|}
\hline \multirow[t]{2}{*}{$\begin{array}{l}\text { Group of } \\
\text { definitions }\end{array}$} & \multirow[t]{2}{*}{ Local insect definition } & \multirow[t]{2}{*}{ English translation } & \multicolumn{2}{|c|}{$\begin{array}{c}\text { Frequency of } \\
\text { mention (number of } \\
\text { people) }\end{array}$} \\
\hline & & & Women & Men \\
\hline \multirow{6}{*}{$\begin{array}{l}\text { Harmful for plants } \\
\text { and people, insects } \\
\text { in general }\end{array}$} & "Animales que atacan las plantas y pican personas" & Animals that attack plants and sting people & 1 & 2 \\
\hline & "Son malos para los sembríos y para el campesino" & They are prejudicial for crops and farmers & 1 & \\
\hline & "Son animales que vuelan y pican" & Animals that fly and sting & 1 & \\
\hline & "Pican a la gente y transmiten enfermedades" & They sting people and transmit diseases & 1 & 3 \\
\hline & "Hacen que la gente se enferme y pierda la comida" & They make people ill and make people lose food & & 1 \\
\hline & "Animales que hacen daño" & Animals that hurt & 1 & \\
\hline \multirow[t]{4}{*}{$\begin{array}{l}\text { Harmful for plants, } \\
\text { insects in general }\end{array}$} & $\begin{array}{l}\text { "Es un animal que ataca y que puede matar a las } \\
\text { plantas" }\end{array}$ & Animal that attack plans and can kill them & 1 & \\
\hline & "Son plagas" & They are pests & 4 & 5 \\
\hline & "Son parásitosde las plantas" & They are parasites of plants & 1 & 2 \\
\hline & "Malogran los sembríos" & They damage crops & 5 & 4 \\
\hline \multirow{5}{*}{$\begin{array}{l}\text { Harmful for plants, } \\
\text { related to a specific } \\
\text { insect }\end{array}$} & "Mariposa que pone los huevos y que afecta las plantas" & Butterfly that lay eggs and affects plants & & 1 \\
\hline & "Chinches que comen hojas de las plantas" & Leaf footed bugs that eat leaves of plants & & 1 \\
\hline & "Gusanos que malogran las plantas" & Worms that cause plant damage & 1 & 4 \\
\hline & "Mariposa que pone huevos" & "Butterfly that lay worms" & & 1 \\
\hline & "El papaso pone los gusanos en el plátano y lo malogra" & $\begin{array}{l}\text { The adult of a butterfly lay worms on plantain and } \\
\text { damage it }\end{array}$ & 1 & \\
\hline \multirow{2}{*}{$\begin{array}{l}\text { Not a negative } \\
\text { perception }\end{array}$} & "Hay insectos buenos y malos para las plantas" & Insects are both beneficial and harmful & & 1 \\
\hline & "Son animales que tienen muchas patas" & Animals with many legs & 1 & \\
\hline
\end{tabular}

Data obtained from 44 people (19 women and 25 men).

pests, and results might have been different if the question would have been framed differently (e.g., which are the insects present in the fields where specific crops are cultivated). Third, given that data was collected in written form, the length of the lists might be affected by men's and women's writing skills (although support was provided during the exercise). Four, only practical LK was documented, but not actual management practices. Finally, factors such as age, household composition, and income, which could also explain variation in LK were not part of the scope of this study. Despite these limitations, the study yields valuable insights into the understanding of the relations between the theoretical and practical LK of entomofauna in the context of socio-cultural and climate change.

\section{RESULTS}

\section{Theoretical LK of Entomofauna Associated With Staple Crops \\ Emic Definition of Insects}

Both men and women in Santa Lucía showed a negative perception of entomofauna associated with cassava, maize, and plantain. They considered insects to be harmful. Most definitions were related to their harm to plants and people, or their harm to plants only (i.e., related to insects in general or specific insects). For example, some general definitions for insects were "insects are pests," "insects are worms that cause plant damage," and "insects damage crops," except for two people who mentioned that "insects are animals with many legs" and "insects are both beneficial and harmful" (Table 1).

\section{Cognitive Salience of Insects}

The results of cognitive salience indexes are in Table 2. Four insects, all pests, were mentioned for cassava. The most mentioned insects were "curuinsi" leafcutter ant (Atta spp.) by $73 \%$ of women and $64 \%$ of men, and "gusano blanco" stemborer (Chilomima spp.) by $84 \%$ of women and $60 \%$ of men. Five insect pests and one beneficial insect were mentioned for maize. The most mentioned pest was "gusano cogollero" armyworm (Spodoptera frugiperda) by $73 \%$ of women and $84 \%$ of men, and the beneficial one was "abejas" bees (Apis spp.) elicited by $42 \%$ of women and $28 \%$ of men. One pest and one beneficial insect were mentioned for plantain. The insect pest was "suri de plátano" giant moth borer (Castnia licus), and the beneficial insect was "hormiga" (ant) mentioned by $20 \%$ of men and $16 \%$ of women. Pests for the three crops were compared with the literature, which indicates that these insects have also been described as pests following an etic approach (Table 3).

The least salient insects (i.e., elicited by less than five persons) were "avispa" (wasp), araña (spider), and "lombriz" (earthworm) for cassava, "mosca blanca" (white fly), "mosca" (fly), and "comején" (termites) for maize; and "araña" (spider), "comején" (termites), and "alacrán” (scorpion) for plantain.

The insect list length was not significantly different between men and women for cassava (median $=3$, interquartile range $=2$ for women; median $=3$, interquartile range $=1$ for men; 
TABLE 2 | Most salient insects associated with cassava, maize, and plantain listed by mestizo women and men, indicating the percentage of women and men that mentioned each insect and their corresponding Sutrop's cognitive salience index (CSI).

\begin{tabular}{|c|c|c|c|c|c|c|}
\hline \multirow[t]{2}{*}{ Crop } & \multicolumn{2}{|c|}{ Insect } & \multicolumn{2}{|c|}{ Women } & \multicolumn{2}{|c|}{ Men } \\
\hline & Common name & Taxonomy & CSI & $\begin{array}{c}\text { percentage } \\
(n=19)\end{array}$ & CSI & $\begin{array}{c}\text { percentage } \\
(n=25)\end{array}$ \\
\hline \multirow[t]{4}{*}{ Cassava } & Curuinsi (leaf cutter ants) & $\begin{array}{l}\text { Order: Hymenopetra } \\
\text { Family: Formicidae } \\
\text { Atta spp. }\end{array}$ & 0.69 & 73 & 0.47 & 64 \\
\hline & Gusano blanco (stemborer) & $\begin{array}{l}\text { Order: Lepidoptera } \\
\text { Family: Pyralidae } \\
\text { Chilomima spp. }\end{array}$ & 0.40 & 84 & 0.32 & 60 \\
\hline & Gusano cornegacho & $\begin{array}{l}\text { Order: Lepidoptera } \\
\text { Family: Sphingidae } \\
\text { Manduca spp. }\end{array}$ & 0.15 & 31 & 0.05 & 8 \\
\hline & Grillo (grasshopper) & $\begin{array}{l}\text { Order: Orthoptera } \\
\text { Family: Acrididae }\end{array}$ & 0.05 & 16 & 0.16 & 36 \\
\hline \multirow[t]{6}{*}{ Maize } & Gusano cogollero (fall armyworm) & $\begin{array}{l}\text { Order: Lepidoptera } \\
\text { Family: Noctuidae } \\
\text { Spodoptera frugiperda }\end{array}$ & 0.57 & 73 & 0.65 & 84 \\
\hline & Chinche (leaf footed bugs) & $\begin{array}{l}\text { Order: Hemiptera } \\
\text { Family: Coreidae }\end{array}$ & 0.05 & 5 & 0.21 & 48 \\
\hline & Abeja (bee) & $\begin{array}{l}\text { Order: Hymenopetra } \\
\text { Family: Apidae } \\
\text { Apis spp. }\end{array}$ & 0.24 & 42 & 0.12 & 28 \\
\hline & Gorgojo (weevil) & $\begin{array}{l}\text { Order: Coleoptera } \\
\text { Family: Bostrichidae }\end{array}$ & 0.14 & 21 & 0.02 & 12 \\
\hline & Grillo (grasshopper) & $\begin{array}{l}\text { Order: Orthoptera } \\
\text { Family: Acrididae }\end{array}$ & 0.08 & 21 & 0.12 & 36 \\
\hline & Curuinsi (leaf cutter ants) & $\begin{array}{l}\text { Order: Hymenopetra } \\
\text { Family: Formicidae } \\
\text { Atta spp. }\end{array}$ & 0.06 & 21 & 0.12 & 36 \\
\hline \multirow[t]{2}{*}{ Plantain } & Suri de plátano (giant moth borer) & $\begin{array}{l}\text { Order: Lepidoptera } \\
\text { Family: Castnidae } \\
\text { Castnia licus }\end{array}$ & 0.57 & 73 & 0.66 & 92 \\
\hline & Hormiga (ant) & $\begin{array}{l}\text { Order: Hymenoptera } \\
\text { Family: Formicidae }\end{array}$ & 0.08 & 16 & 0.04 & 20 \\
\hline
\end{tabular}

Data were obtained from 44 people (19 women and 25 men).

$\mathrm{W}=214, p=0.5692$ ), and plantain (median $=3$, interquartile range $=1$ for women; median $=2$, interquartile range $=2$ for men; $\mathrm{W}=174, p=0.11$ ). However, for maize, men provided significantly longer lists (median $=2$, interquartile range $=2$ for women; median $=3$, interquartile range $=2$ for men; $\mathrm{W}=336.5$, $\left.p<0.05^{*}\right)$.

\section{Practical LK: Management Strategies Associated With the Entomofauna}

For women, $50 \%$ of insects did not have any associated management practices, $30 \%$ had sustainable practices (mainly curative such as the manual elimination of worms), and $20 \%$ unsustainable practices (such as spraying pesticides). For men, $40 \%$ of insects did not have any associated management practice, $40 \%$ had sustainable practices (both curative and preventive), and $20 \%$ had unsustainable practices.

Some curative strategies practiced by men are manual elimination of worms and eggs. The preventive strategies mentioned by men are terrain preparation (putting ashes around the plant to prevent moths from laying their eggs), site selection (planting in clay soil instead of sandy soil) and cultivating insecticidal plants around crop fields. For example, planting "rosasisa," also known as African marigold (Tagetes erecta L), around cassava and maize fields is a practice to manage Atta spp. "Rosasisa" acts as an insecticidal plant when the ant feeds on it instead of crops. However, during focus groups, men mentioned that if they could afford to buy agrochemicals to manage Atta spp., they would apply them instead of "rosasisa," because growing "rosasisa" requires extra time and work.

Women considered a curative strategy as the main management strategy to manage "gusano blanco" stemborer (Chilomima spp.) in cassava, which is the manual elimination of the worms. In contrast, men mentioned a preventive strategy that consists of planting cassava in clay soil instead of sandy soil, as stemborers increase in sandy areas. A similar result was found for managing "suri de plátano" giant month borer (Castnia licus) in plantain, i.e., women mentioned a curative strategy of manual elimination of eggs, larvae, and damaged stems; while men mentioned a preventive strategy that consists of putting ashes 
TABLE 3 | Etic description of the most salient insects identified by women and men based on the literature.

\begin{tabular}{|c|c|c|c|c|}
\hline Crop & Common name & Taxonomy & Description & References \\
\hline \multirow[t]{4}{*}{ Cassava } & $\begin{array}{l}\text { Curuinsi (leaf cutter } \\
\text { ants) }\end{array}$ & $\begin{array}{l}\text { Order: Hymenopetra } \\
\text { Family: Formicidae } \\
\text { Atta spp. }\end{array}$ & $\begin{array}{l}\text { It is a generalist species that cut leaves of different crops, but it can produce } \\
\text { total losses of the crop if is not controlled }\end{array}$ & Vanegas, 2018 \\
\hline & $\begin{array}{l}\text { Gusano blanco } \\
\text { (stemborer) }\end{array}$ & $\begin{array}{l}\text { Order: Lepidoptera } \\
\text { Family: Pyralidae } \\
\text { Chilomima spp. }\end{array}$ & $\begin{array}{l}\text { It is considered one of the most important pests for cassava. Females put } \\
\text { the eggs near to the bud and the caterpillar eats from de cortex to the stem, } \\
\text { thus perforations fracture the stem producing low yields of roots }\end{array}$ & $\begin{array}{l}\text { Ospina and } \\
\text { Ceballos, 2002; } \\
\text { Perozo et al., } \\
2007\end{array}$ \\
\hline & Gusano cornegacho & $\begin{array}{l}\text { Order: Lepidoptera } \\
\text { Family: Sphingidae } \\
\text { Manduca spp. }\end{array}$ & $\begin{array}{l}\text { It is a pest that affects in less proportion cassava than other pests such as } \\
\text { Chilomima spp., but it can defoliated a complete plant if is not controlled }\end{array}$ & $\begin{array}{l}\text { Nicaragua et al., } \\
2004\end{array}$ \\
\hline & Grillo (grasshopper) & $\begin{array}{l}\text { Order: Orthoptera } \\
\text { Family: Acrididae }\end{array}$ & $\begin{array}{l}\text { They are generalist species that attack not only cassava, but different crops. } \\
\text { They cut plants after hatching, also cause damage on the base of the plant } \\
\text { leaving it susceptible to overturning }\end{array}$ & $\begin{array}{l}\text { Ospina and } \\
\text { Ceballos, } 2002\end{array}$ \\
\hline Maize & $\begin{array}{l}\text { Gusano cogollero } \\
\text { (fall armyworm) }\end{array}$ & $\begin{array}{l}\text { Order: Lepidoptera } \\
\text { Family: Noctuidae } \\
\text { Spodoptera } \\
\text { frugiperda }\end{array}$ & $\begin{array}{l}\text { This species prefers maize, but can cause significant damage to } 80 \text { species } \\
\text { of crops. Female moth put the eggs on the leaves, after hatching the } \\
\text { caterpillars feed on leaves and move to the protective region on the whorl, } \\
\text { resulting in ragged holes in the leaves. If feeding is on young parts, the } \\
\text { growing point is killed resulting in no new leaves or cob developing. But, if } \\
\text { the plant have developed cobs, the larvae will feed on the kernels }\end{array}$ & $\begin{array}{l}\text { Food and } \\
\text { Agriculture } \\
\text { Organization of } \\
\text { the United } \\
\text { Nations (FAO), } \\
2018\end{array}$ \\
\hline \multirow[t]{2}{*}{ Plantain } & $\begin{array}{l}\text { Suri de plátano } \\
\text { (giant moth borer) }\end{array}$ & $\begin{array}{l}\text { Order: Lepidoptera } \\
\text { Family: Castnidae } \\
\text { Castnia licus }\end{array}$ & $\begin{array}{l}\text { This species attack plantain, coconut and sugar cane. The moth lay the } \\
\text { eggs on dry leaves of plantain and when the caterpillar hatches it tunnels } \\
\text { into the stem and destroy it affecting plant development and fruit production }\end{array}$ & $\begin{array}{l}\text { Vela Panduro } \\
\text { and Marca, } 2007\end{array}$ \\
\hline & Hormiga (ant) & $\begin{array}{l}\text { Order: Hymenoptera } \\
\text { Family: Formicidae }\end{array}$ & It feeds on the eggs of $C$. licus helping to control it naturally & Skinner, 1930 \\
\hline
\end{tabular}

around the plant to prevent moths from laying their eggs on the plant (Tables 4, 5).

Women considered bees to be pests because they believed that they fed on maize flowers, causing maize kernels to not develop properly. In contrast, some men mistakenly considered bees to be important insects for maize pollination, although maize is pollinated by wind. In either case, they did not know of any practices to conserve them. "Hormigas" were considered beneficial by men and women, since they fed on the eggs of "suri de plátano" (Castnia licus), helping to decrease the number of emerging moths. Both male and female farmers did not report using any practices to preserve beneficial insects (Tables 4, 5).

\section{Perceived Effects of Climate Change on Entomofauna}

People in Santa Lucía identified the following indicators of climate change in order of severity (i.e., starting with indicators that most negatively affect agriculture): (1) increase in rainfall, (2) increase in temperature, and (3) heavy winds. Farmers mentioned that the first two indicators have negatively affected crop production and increased pests (Tables 4,5 ). The last indicator affected crop production because it overturned the plants but did not affect pests. Men and women agreed on the effects of the indicators of climate change on most insects identified as prominent for each crop, except for the effects on "gusano cogollero" armyworm (Spodoptera frugiperda), and "abejas" Apis spp. (Tables 3, 4). Armyworm increases were associated with high temperature for women and with rains for men. Bees would be affected by high temperatures according to men, but not women.

\section{DISCUSSION}

The hypothesis "smallholder farmers mainly distinguish pests over beneficial insects associated with cassava, maize, and plantain (theoretical LK), and this is reflected in their practical LK (i.e., the absence of sustainable practices to protect beneficial insects and reduce the incidence of pests)" was only partly fulfilled based on the results of the study conducted in Santa Lucía village. Regarding the first part of the hypothesis, most of the most salient insects are pests. For instance, while eight out of 11 of the most salient insects were classified as pests by all informants, only two out of 11 were regarded as beneficial by $<34 \%$ of informants. Of these, $16 \%$ of women and $20 \%$ of men recognized ants as beneficial to manage "suri de plátano" (C. licus) in plantain, and $28 \%$ of men explained that bees are important maize pollinators (while maize is pollinated by wind), and $42 \%$ of women classified bees as pests. The negative connotation of insects starts from their emic definition of the cultural domain "insect," where both men and women considered insects harmful for crops. Our results are aligned with Bentley and Rodríguez (2001), who argued that farmers mostly recognize insects that are culturally important such as disease organisms or pests of crops.

Regarding the second part of the hypothesis, the lack of knowledge of most informants about beneficial insects was 
TABLE 4 | Practical knowledge of common management strategies associated with entomofauna among women.

\begin{tabular}{|c|c|c|c|c|c|}
\hline \multirow[t]{2}{*}{ Crop } & \multicolumn{2}{|c|}{ Insect } & \multirow[t]{2}{*}{ Crop effect } & \multirow[t]{2}{*}{ Management strategy } & \multirow[t]{2}{*}{ Climate effects } \\
\hline & Common name & Taxonomy & & & \\
\hline \multirow[t]{7}{*}{ Cassava } & Curuinsi (leaf cutter ants) & $\begin{array}{l}\text { Order: Hymenopetra } \\
\text { Family: Formicidae } \\
\text { Atta spp. }\end{array}$ & Breaks the stem and eats the leaves & Pesticides if they can afford them & Not affected by climate \\
\hline & Gusano blanco (stemborer) & $\begin{array}{l}\text { Order: Lepidoptera } \\
\text { Family: Pyralidae } \\
\text { Chilomima spp. }\end{array}$ & Eats the stem and leaves & Manual elimination, birds eat them & $\begin{array}{l}\text { Increases with high } \\
\text { temperatures }\end{array}$ \\
\hline & Gusano cornegacho & $\begin{array}{l}\text { Order: Lepidoptera } \\
\text { Family: Sphingidae } \\
\text { Manduca spp. }\end{array}$ & Breaks the leafs when the plant is juvenile & Manual elimination & Increase with rains \\
\hline & Grillo (grasshopper) & $\begin{array}{l}\text { Order: Orthoptera } \\
\text { Family: Acrididae }\end{array}$ & Feeds in the whorl when the plant is juvenile & No action taken & Increase with rains \\
\hline & $\begin{array}{l}\text { Gusano cogollero (fall } \\
\text { armyworm) }\end{array}$ & $\begin{array}{l}\text { Order: Lepidoptera } \\
\text { Family: Noctuidae } \\
\text { Spodoptera frugiperda }\end{array}$ & Feeds in the whorl & No action taken & $\begin{array}{l}\text { Increases with high } \\
\text { temperatures }\end{array}$ \\
\hline & Chinche (leaf footed bugs) & $\begin{array}{l}\text { Order: Hemiptera } \\
\text { Family: Coreidae }\end{array}$ & Burns the leaves & No action taken & Increases with rains \\
\hline & Abeja (bee) & $\begin{array}{l}\text { Order: Hymenopetra } \\
\text { Family: Apidae } \\
\text { Apis spp. }\end{array}$ & $\begin{array}{l}\text { Steals pollen which makes corn kernels not to } \\
\text { grow }\end{array}$ & No action taken & Not affected by climate \\
\hline \multirow[t]{3}{*}{ Maize } & Gorgojo (weevil) & $\begin{array}{l}\text { Order: Coleoptera } \\
\text { Family: Bostrichidae }\end{array}$ & Eats the grain & $\begin{array}{l}\text { Pesticides (Phosfin tablets located } \\
\text { between bags of maize inside a } \\
\text { container) }\end{array}$ & $\begin{array}{l}\text { Increases with high } \\
\text { temperatures }\end{array}$ \\
\hline & Grillo (grasshopper) & $\begin{array}{l}\text { Order: Orthoptera } \\
\text { Family: Acrididae }\end{array}$ & Breaks the stem & No action taken & Not affected by climate \\
\hline & Curuinsi (leaf cutter ants) & $\begin{array}{l}\text { Order: Hymenopetra } \\
\text { Family: Formicidae } \\
\text { Atta spp. }\end{array}$ & Eats grain and leaves & Pesticides if they can afford them & Not affected by climate \\
\hline \multirow[t]{2}{*}{ Plantain } & $\begin{array}{l}\text { Suri de plátano (giant moth } \\
\text { borer) }\end{array}$ & $\begin{array}{l}\text { Order: Lepidoptera } \\
\text { Family: Castnidae } \\
\text { Castnia licus }\end{array}$ & $\begin{array}{l}\text { The butterfly put eggs in the stem, the larvae } \\
\text { enters into the stem and kill the plant }\end{array}$ & $\begin{array}{l}\text { Manual elimination of eggs, larvae } \\
\text { and damage stems }\end{array}$ & Not affected by climate \\
\hline & Hormiga (ant) & Order: Hymenoptera & They kill "suri de plátano" & Do not kill it & Not affected by climate \\
\hline
\end{tabular}


TABLE 5 | Practical knowledge of common management strategies associated with entomofauna among men.

\begin{tabular}{|c|c|c|c|c|c|}
\hline \multirow[t]{2}{*}{ Crop } & \multicolumn{2}{|c|}{ Insect } & \multirow[t]{2}{*}{ Crop effect } & \multirow[t]{2}{*}{ Management strategy } & \multirow[t]{2}{*}{ Climate effects } \\
\hline & Common name & Taxonomy & & & \\
\hline \multirow[t]{7}{*}{ Cassava } & Curuinsi (leaf cutter ants) & $\begin{array}{l}\text { Order: Hymenopetra } \\
\text { Family: Formicidae } \\
\text { Atta spp. }\end{array}$ & $\begin{array}{l}\text { Eats the leaves, the root hardens and is not } \\
\text { palatable to eat }\end{array}$ & $\begin{array}{l}\text { Planting Rosasisa (Tagetes erecta L.) } \\
\text { that kill the ant or using poison } \\
\text { Pesticides if they can afford them }\end{array}$ & Not affected by climate \\
\hline & Gusano blanco (stemborer) & $\begin{array}{l}\text { Order: Lepidoptera } \\
\text { Family: Pyralidae } \\
\text { Chilomima spp. }\end{array}$ & Breaks the stem & $\begin{array}{l}\text { Avoid planting in sandy soil because } \\
\text { the worm increases, planting should } \\
\text { be in clay soil }\end{array}$ & $\begin{array}{l}\text { Increases with high } \\
\text { temperatures }\end{array}$ \\
\hline & Gusano cornegacho & $\begin{array}{l}\text { Order: Lepidoptera } \\
\text { Family: Sphingidae } \\
\text { Manduca spp. }\end{array}$ & Eats the leaves & Manual elimination & Increase with rains \\
\hline & Grillo (grasshopper) & $\begin{array}{l}\text { Order: Orthoptera } \\
\text { Family: Acrididae }\end{array}$ & Eats the branches & No action taken & Increase with rains \\
\hline & $\begin{array}{l}\text { Gusano cogollero (fall } \\
\text { armyworm) }\end{array}$ & $\begin{array}{l}\text { Order: Lepidoptera } \\
\text { Family: Noctuidae } \\
\text { Spodoptera frugiperda }\end{array}$ & $\begin{array}{l}\text { Feeds in the whorl of corn, perforates the } \\
\text { leaves }\end{array}$ & $\begin{array}{l}\text { Wait for heavy rains to flood the stem } \\
\text { and kill it } \\
\text { Manual elimination }\end{array}$ & $\begin{array}{l}\text { It appears after dry } \\
\text { periods and increase with } \\
\text { rains }\end{array}$ \\
\hline & Chinche (leaf footed bugs) & $\begin{array}{l}\text { Order: Hemiptera } \\
\text { Family: Coreidae }\end{array}$ & Dries the Leaf and delay corn production & No action taken & $\begin{array}{l}\text { Increase with heavy rains } \\
\text { and dryness }\end{array}$ \\
\hline & Abeja (bee) & $\begin{array}{l}\text { Order: Hymenopetra } \\
\text { Family: Apidae } \\
\text { Apis spp. }\end{array}$ & Bees contribute to produce maize & No action taken & $\begin{array}{l}\text { Decrease with high } \\
\text { temperatures }\end{array}$ \\
\hline \multirow[t]{3}{*}{ Maize } & Gorgojo (weevil) & $\begin{array}{l}\text { Order: Coleoptera } \\
\text { Family: Bostrichidae }\end{array}$ & Eats the grain & $\begin{array}{l}\text { Wash the cob } \\
\text { Pesticides (Phosfin tablets located } \\
\text { between bags of maize inside a } \\
\text { container) }\end{array}$ & Increase in hot periods \\
\hline & Grillo (grasshopper) & $\begin{array}{l}\text { Order: Orthoptera } \\
\text { Family: Acrididae }\end{array}$ & $\begin{array}{l}\text { Breaks the trunk when it is emerging and kills } \\
\text { the plant }\end{array}$ & No action taken & Increase with rains \\
\hline & Curuinsi (leaf cutter ants) & $\begin{array}{l}\text { Order: Hymenopetra } \\
\text { Family: Formicidae } \\
\text { Atta spp. }\end{array}$ & Eat the leaves & $\begin{array}{l}\text { Planting Rosasisa (Tagetes erecta L.) } \\
\text { that kill the ant or using poison } \\
\text { Pesticides if they can afford them }\end{array}$ & Not affected by climate \\
\hline \multirow[t]{2}{*}{ Plantain } & $\begin{array}{l}\text { Suri de plátano (giant moth } \\
\text { borer) }\end{array}$ & $\begin{array}{l}\text { Order: Lepidoptera } \\
\text { Family: Castnidae Castnia licus }\end{array}$ & Eats the whorl and affect fruit production & $\begin{array}{l}\text { Kill manually the eggs of the moth } \\
\text { and put ash surrounding the plant to } \\
\text { prevent the butterfly to put the eggs }\end{array}$ & Not affected by climate \\
\hline & Hormiga (ant) & Order: Hymenoptera & Eats "Suri de plátano" & Do not kill it & Decrease with heavy rains \\
\hline
\end{tabular}


reflected by the lack of management practices to preserve or promote them. While most management practices reported were mainly to control pests, half of the insects lacked any type of management practice. The other half of insects were managed by sustainable (curative and preventive) or unsustainable (e.g., use of pesticides) management practices. In addition, farmers explained during focus groups that they would use more pesticides if they could afford to buy them. Our results agree with previous studies that reported that a lack of ecological literacy among farmers has consequences for the farming management practices that they use. For example, it was reported that many potato farmers in the Kabale, Kisoro, Mbale, Kapchorwa, Mubende, and Kyegegwa districts in Uganda lacked knowledge about the natural enemies of potato pests, which resulted in them using pesticides for pest control (Okonya and Kroschel, 2016). Similar results were found in Maranda, Asego, Uranga, Lambwe, and Madiany districts in Kenya where a lack of knowledge about the natural enemies of cotton pests was reflected in the indiscriminate use of pesticides (Midega et al., 2012). LK on agroecological practices for pest management must be improved to prevent the widespread use of unsustainable management practices (such as the excessive use of harmful pesticides) which could have a detrimental effect on local ecosystems, and ultimately on local food security, health, and biodiversity conservation.

One of the explanations for the lack of recognition of beneficial insects is that mestizo smallholder farmers in Santa Lucía recently settled in the village: i.e., they migrated in the 1980s from other provinces of Loreto and in the last 10 years from the highlands of Peru. They came from regions with different environmental characteristics, culture, and farming activities, and started new productive activities in the Amazon region. In contrast with inter-generational processes of knowledge transmission, which are typical of indigenous peoples who have long-term history and knowledge of the environment where they live, mestizos' knowledge of the crops, their agronomy, and the local entomofauna have been acquired by recent trial and error (e.g., while experimenting with crops that might have been new to them), and/or transmitted from other mestizos or indigenous peoples from surrounding villages. There have been similar findings from another region of the Peruvian Amazon where mestizo children were found to have lost or failed to acquire knowledge about food plants due to socio-cultural change in the region (Cruz-Garcia et al., 2018). In contrast, studies conducted with indigenous peoples have reported a thorough knowledge of beneficial insects such as pollinators or natural enemies. For instance, knowledge of bee pollinator systems is found in many cultures: 17 species of stingless bees were identified by people in Yucatan (Mexico), 23 by Hoti people in Venezuela, 25 among Tatuno, Siriano, and Bara people of the Vaupes and Apaporis rivers of Colombia, and 43 by Nukak indigenous from the Colombian Amazon (Hill et al., 2019). The deep knowledge of these indigenous cultures about pollinators was accompanied by bee conservation practices such as the conservation of nesting trees, construction of beehives, protection of flowering resources and forests, and farming diversification represented in agroforestry and home gardening, among others (Hill et al., 2019).

Although most of the insects elicited in Santa Lucía were pests, the number of pests that were identified by local people was lower in comparison to etic knowledge, i.e., with pests reported in the literature for the three crops. On one hand, some publications on crop pests are general and not specific to the Amazon region, therefore they may report pests that are not common to the types of agroecosystems present in Santa Lucía. On the other hand, this might be explained by the fact that Santa Lucía still has subsistence agriculture, characterized by including a diverse mixture of plants for own consumption, instead of intensified monocropping. The diversity in the agricultural fields prevents pest proliferation because a field with a variety of plants does not offer a large block of food for insects (as a monoculture does), so pests will not get the nutrients necessary to proliferate (Davis University of California, 2016; Wetzel et al., 2016). In this study, while only two insects associated with cassava, "curuinsi" (Atta spp.) and "gusano blanco" (Chilomima spp.), were the most cognitively important among participants in Santa Lucía, there are several additional groups of insects that have been recognized as pests for this crop in the literature, including mites, thrips, hornworms, white flies, ants, termites, grasshoppers, gall midges, lace bugs, stem borers, white grubs, fruit flies, shoot flies, scale insects, mealy bugs, and cutworms (Belloti and van Schoonhoven, 1978). Whereas, most men and women in Santa Lucía highlighted "gusano cogollero" (S. frugiperda) as the most important insect associated with maize, there are several pests reported for maize in the literature, including thrips, moths, grasshoppers, and beetles (CESAVEG, 2018). Particularly, "gusano cogollero" (S. frugiperda), "gusano soldado" (Mocis spp.), "barrenador de la caña de azúcar" (Diatraea saccharalis), "gusano choclero" (Helicoverpa zea), and "pulgón del maíz" (Rhopalosiphum maidis), all of which have been reported as maize pests in the region of San Martín, which is located near Yurimaguas, where the study took place (Meléndez, 2013). Most men and women listed "suri de plátano" (C. licus) as the most salient insect for plantain, while it is known that there are other pests including beetles and moths (ICA, 2012). In particular, "suri de plátano" (C. licus) and "gorgojo negro" (Cosmopolites sordidus) have been reported as major pests in the province of Datem del Marañon, Loreto region (Cuñachi, 2014).

Results have shown that farmers in Santa Lucía use sustainable practices to manage entomofauna such as using insecticidal plants and the manual removal of pests. For example, the use of the insecticidal plant "rosasisa" was mentioned by men to manage Atta spp. on cassava and maize. When the plant is cultivated in agricultural fields next to crops, ants transport leaf cuts of "rosasisa" (T. erecta) to the nest for feeding purposes, but the plant has biochemical lethal components for the ant, thus acting as an insecticide. Participants reported that this technique was learned from indigenous people. The use of $T$. erecta as an insecticide has also been reported among indigenous Maya people in Patzun, Guatemala (Morales and Perfecto, 2000). In addition, Parugrug and Roxas (2008) have reported the repellent action of this plan against the maize weevil, Sitophilus zeamais. Likewise, Verma et al. (2009) reported the termiticidal properties 
of $T$. erecta. Another example of sustainable management practices is the manual removal of "gusano blanco" (Chilomima spp.) from cassava plants, reported by women. This is aligned to studies that indicate that the management of this insect is curative, as the use of pesticides is impractical as the insect feeds inside the stems where pesticides cannot reach it (Belloti and van Schoonhoven, 1978; Almonacid et al., 2016). In addition, some men and women have reported that "suri de plátano" (C. licus) is controlled naturally by ants. Certainly, other studies have revealed that ants destroy a considerable proportion of the eggs laid by this moth helping to control their populations (Skinner, 1930). Farmers in Santa Lucía have explained that moths lay eggs covered by phlegm on the plant and ants have been observed feeding on the eggs. The recognition of the eggs by local villagers might have been learned from their observations, from other farmers, or obtained from technical training (although the amount of training was minimal). However, according to the survey mentioned in the study site, only 3 of 20 households in Santa Lucía received training capacity on agricultural practices in 2015-2016.

The results showed that the main indicators of climate change that affect pests are the increase in rainfall and temperature. Similarly, previous participatory rural appraisals conducted in the village (Beltrán-Tolosa et al., 2016) showed that farmers perceived an increase of pests associated with cassava, maize, and plantain in the last 5 years and they ascribed it to the same indicators of climate change. When comparing the findings of this study to etic knowledge, the literature has predicted that insect pest species will respond differently to increased temperatures, depending on their geographical distribution and the target crop (Deutsch et al., 2018). For example, stem borers such as "gusano blanco" (Chilomima spp.) associated with cassava seem to be influenced mainly by temperature, and to a lesser extent by precipitation and relative humidity (Emana et al., 2002; Mutamiswa et al., 2017), which agrees with the observations of local farmers in Santa Lucía. It has also been reported that "gusano cogollero" (S. frugiperda) migrates in response to increases in temperature (Westbrook et al., 2016), which is aligned with the observations of local men and women. Regarding beneficial insects, Schweiger et al. (2010) predicted the decrease in the populations of bees with higher temperatures, as it impacts the abundance, distribution, and phenology of bees and their host plants, which is aligned to men's observations in Santa Lucía. Farmer's resilience to climate change should be improved as it has been predicted that climate change may contribute to an increase in the incidence of crop pests (Deutsch et al., 2018) and decrease in pollinators such as bees, local capacities on the identification, biology, and ecological role of beneficial and pest insects, as well as on sustainable or agroecological management practices.

It is recommended that future studies could delve deeper into understanding local classifications and categorizations of entomofauna supported by qualitative ethnographic work, as well as local processes of knowledge transmission, and documenting actual management practices (and relating them to LK). Future studies might also explore the effect of other factors such as age, household composition, and income, on the variation of LK and practices. Finally, to provide additional insights into the LK of entomofauna under processes of socio-cultural change, future research could also be conducted with indigenous populations from the region.

\section{CONCLUSIONS}

Results showed that in Santa Lucía, a small village at the AAF in Peru, mestizo farmers (men and women) had a negative perception of entomofauna associated with cassava, maize, and plantain because they considered most insects to be harmful to crops. Only a few of them highlighted the existence of beneficial insects such as pollinators and natural enemies. Consequently, the management practices that farmers use are focused on controlling pests, and not on preserving beneficial insects. This is certainly related to the socio-cultural dynamics of mestizos in the forest-agricultural frontier, and that Santa Lucía is a mestizo village, inhabited by migrants who arrived in two migration waves (1960 and 2009) to start new productive activities in an environment new to them. Their crop management knowledge has been acquired by trial and error experiments or has been transmitted from other mestizos or indigenous peoples, and their surroundings.

Although farmers mentioned preventive and curative sustainable management practices for about one third of insects, half of them did not present any associated management practices and the rest only showed unsustainable practices (such as the use of pesticides). Farmers in Santa Lucía explained that they do not apply pesticides commonly because they cannot afford to buy them and were not aware of their negative effects on the biota and environment. The lack of knowledge about beneficial entomofauna and sustainable management practices for pest control might also result in the use of unsustainable practices that may have detrimental effects on the environment and, ultimately, local food security, health, and biodiversity. Therefore, local capacities should be built to enrich theoretical knowledge on the recognition, biology, and ecological role of entomofauna (e.g., pollination, natural predation), and associated management practices (e.g., agroecological practices to manage pests and protect pollinators). The implementation of agroecological practices, alongside the rescue and promotion of existing preventive practices to manage entomofauna such as insecticidal plants (e.g., T. erecta), will strengthen the adaptive capacity of the agroecosystem and decrease farmers' vulnerably to climate change.

\section{DATA AVAILABILITY STATEMENT}

The datasets generated for this study are available on request to the corresponding author.

\section{ETHICS STATEMENT}

Ethical review and approval was not required for the study on human participants in accordance with the local legislation and institutional requirements. The patients/participants provided their written informed consent to participate in this study. 


\section{AUTHOR CONTRIBUTIONS}

LB-T and GC-G conceived the manuscript idea. LB-T developed the theory, collected the data, and wrote the manuscript with support from GC-G. RS collected the data and provided critical feedback to the manuscript. GC-G supervised the study, the findings of this work, and verified the analytical methods. MQ helped supervise the project, discussed the results, and contributed to the final manuscript. All authors contributed to the article and approved the submitted version.

\section{FUNDING}

This work is part of the Sustainable Amazonian Landscapes (SAL) project, which is part of the International Climate Initiative

\section{REFERENCES}

Almonacid, R., Aguirre, M., Velozo, L., and Cáceres, S. (2016). Estación experimental agropecuaria bellavista-hoja de divulgación 48 El barrenador del tallo, plaga del cultivo de mandioca: estación experimental agropecuaria Bellavista. Hoja de divulgación $N^{\circ}$ 48:8. Available online at: https://inta.gob. ar/sites/default/files/inta_hd48_el_barrenador_del_tallo_-_plaga_del_cultivo_ de_la_mandioca.pdf

Altieri, M. A. (2002). Agroecology: the science of natural resource management for poor farmers in marginal environments. Agr. Ecosyst. Environ. 93, 1-24. doi: 10.1016/S0167-8809(02)00085-3

Altieri, M. A., Nichols, C. I., Henao, A., and Lana, M. A. (2015). Agroecology and the design of climate change-resilient farming systems. Agro. Sustain. Dev. 35, 869-890. doi: 10.1007/s13593-015-0285-2

Autoridad Nacional del Agua (ANA) del Peru (2018). In Forme Técnico Para la Identificación de las Zonas de Riesgo del Caser?o Santa Lucía, Distrito de Yurimaguas, Provincia de Alto Amazonas, Yurimaguas.

Barrera-Bassols, N., and Toledo, V. M. (2005). Ethnoecology of the Yucatec Maya: symbolism, knowledge and management of natural resources. J. Lat. Am. Geogr. 4, 9-41. doi: 10.1353/lag.2005.0021

Belloti, A., and van Schoonhoven, A. (1978). Cassava Pests and Their Control. Palmira: Centro Internacional de Agricultura Tropical (CIAT).

Beltrán-Tolosa, L. M., Cruz, G., Peters, P., Sachet, E., and Vanegas, M. (2016). Desarrollo de Métodos Participativos: Santa Lucía, Yurimaguas. Paisajes Sostenibles para la Amazonía. Cali. Colombia: Centro Internacional de Agricultura Tropical (CIAT).

Beltrán-Tolosa, L. M., Navarro-Racines, C., Pradhan, P., Cruz-Garcia, G. S., Solis, R., and Quintero, M. (2020). Action needed for staple crops in the Andean-Amazon foothills because of climate change. Mitig. Adapt. Strateg. Glob. Chang. 25, 1103-1127. doi: 10.1007/s11027-020-0 9923-4

Bentley, J. W., and Rodríguez, G. (2001). Honduran Folk Entomology. Curr. Anthropol. 42, 285-299. doi: 10.1086/320010

Berkes, F. (1999). Sacred Ecology: Traditional Ecological Knowledge and Resource Management. Philadelphia, PA: Taylor \& Francis.

Borgatti, S. P. (1998). "Elicitation techniques for cultural domain analysis," in The Ethnographer's Toolkit, eds J. Schensul and M. LeCompte (Walnut Creek, CA: Altimira Press), 1-26.

Borror, D. J., and De Long, D. M. (1988). Introdução Ao Estudo Dos Insetos. São Paulo: Edgard Blücher.

CESAVEG (2018). Manual de Plagas y Enfermedades En Maiz. Guanajuato. Available online at: https://infoagronomo.net/plagas- $y$-enfermedades-delmaiz/

Cruz-Garcia, G. S., Caffi, C., Chuspe Zans, M. E., and Sanchez-Choy, J. (2018). Children's knowledge of wild food plants in the forest-agriculture interface. J. Ethnobiol. 38, 205-222. doi: 10.2993/0278-0771-38.2.205

Cuñachi, F. (2014). Determinación de los factores de sostenibilidad de cultivo de Musa spp., plátano, en la zona de la provincia del Datem del Marañón, Region
(IKI). The German Federal Ministry for the Environment, Nature Conservation, Building and Nuclear Safety (BMUB) support this initiative on the basis of a decision adopted by the German Bundestag. This study is part of the Ph.D. dissertation of LB-T at Universidad Nacional de Colombia, sede Palmira. The Ph.D. was funded by Instituto Colombiano para el Desarrollo de la Ciencia y la Tecnología de Colombia (COLCIENCIAS).

\section{ACKNOWLEDGMENTS}

We would like to thank Jhon Ocampo and Jorge Parra for their comments and Joel Vasquez for the taxonomic identification of insects. Finally, we are grateful to the families from Santa Lucía (Yurimaguas, Peru) who kindly participated in this study, making this project possible.

Loreto (Ph.D. thesis). Para optar al título de Ingeniero Agronomo, Universidad Nacional de la Amazonía Peruana, Facultad de Agronomía, Iquitos, Peru.

Davis University of California (2016). Why Insect Pests Love Monocultures, and How Plant Diversity Could Change tha ScienceDaily. Available online at: www. sciencedaily.com/releases/2016/10/161012134054.htm

Deutsch, C. A., Tweksbury, J. J., Tigchelaar, M., Battisti, D. S., Merrill, S. C., Huey, R. B., et al. (2018). Increase in crop losses to insect pests in a warming climate. Science 361, 916-919. doi: 10.1126/science.aat3466

Dinerstein, E., Olsen, D., Joshi, A., Vynne, C., Burgess, N. D., Wikramanayake, E., et al. (2017). An ecoregion-based approach to protecting half the terrestrial realm. BioScience 67, 534-545. doi: 10.1093/biosci/bix014

Dovie, D. B. K., Witkowski, E. T. F., and Shackleton, C. M. (2008). Knowledge of plant resource use based on location, gender and generation. Appl. Geogr. 28, 311-322. doi: 10.1016/j.apgeog.2008.07.002

Emana, G., Overholt, W. A., Kairu, E., and MacOpiyo, L. (2002). Predicting the distribution of Chilo partellus (Swinhoe) and its parasitoid Cotesia flavipes Cameron in Ethiopia using correlation, step-wise regression and geographic information systems. Int. J. Trop. Ins. Sci. 22, 123-129. doi: $10.1017 /$ S1742758400015204

Finer, M., Vijay, V., and Mamani, N. (2018). Línea Base de Palma Aceitera Para la Amazonía Peruana. Loreto: Monitoring of the Andean Amazon Project. Available online at: https://maaproject.org/2018/palma-aceitera-peru/

Food and Agriculture Organization of the United Nations (FAO) (2018). Integrated Management of the Fall Armyworm on Maize. Rome: FAO.

Gatewood, J. (1984). Familiarity, vocabulary size, and recognition ability in four semantic domains. Am. Ethnol. 11:507-527. doi: 10.1525/ae.1984.11.3.02a00060

Goulson, D., Nicholls, E., Botías, C., and Rotheray, E. L. (2015). Bee declines driven by combined stress from parasites, pesticides, and lack of flowers. Science 347:1255957. doi: 10.1126/science. 1255957

Gurung, A. B. (2003). 'Insects - a mistake in God's creation? Tharu farmers' perception and knowledge of insects: a case study of Gobardiha Village Development Committee, Dang-Deukhuri, Nepal. Ag. Hum. Values 20, 337-370. doi: 10.1023/B:AHUM.0000005149.30242.7f

Hill, R., Nates-Parra, G., Quezada-Euan, J. J. G., Buchori, D., LeBuhn, G., Maues, M. M., et al. (2019). Biocultural approaches to pollinator conservation. Nat. Sustain. 2, 214-222. doi: 10.1038/s41893-019-0244-Z

Huamán Espino, L., and Valladares, C. E. (2006). Estado nutricional y características del consumo alimentario de la población aguaruna. Rev. Peru Med. Exp. Salud. Publica 23, 12-21. Available online at: http://www.scielo.org. pe/scielo.php?script=sci_arttext\&pid=S1726-46342006000100003

ICA (2012). Manejo Fitosanitario Del Cultivo de Plátano (Musa Spp). Bogotá: Produmedios.

Kasina, M. J., Kraemer, M., Martius, C., and Wittmann, D. (2009). Farmers knowledge of bees and their natural history in Kakamega district, Kenya. J. Apicul. Res. 48,126-133. doi: 10.3896/IBRA.1.48.2.07

López De La Cruz, E., Ruíz Montoya, L., Gómez y Gómez, B., Castro Ramírez, A. E., and Sánchez Cortés, M. S. (2018). Conocimiento y percepción 
tsotsil sobre los insectos perjudiciales para la milpa en la reserva de la selva El Ocote (Chiapas, México). Estud. Cult. Maya. 52, 255-290. doi: 10.19130/iifl.ecm.2018.52.882

Martin, G. J. (2004). Ethnobotany: a Methods Manual. London: Chapman and Hall. Meléndez, E. H. (2013). Manejo Técnico del Cultivo de Maíz Amarillo Duro en la Región de San Martín. Tarapoto; Lima: Ministerio de Agricultura y riego, Institutoo Nacional de Innovación Agraria (INIA). Estación Experimental Agraria el Porvenir. Folleto $\mathrm{N}^{\circ} 2-13$. Available online at: http://repositorio.inia. gob.pe/bitstream/inia/149/1/Cultivo_maiz_amarillo_2013.pdf

Midega, C. A. O., Nyang'au, I. M., Pittchar, J., Birkett, M. A., Pickett, J. A., Borges, M., et al. (2012). Farmers' perceptions of cotton pests and their management in Western Kenya. Crop Prot. 42, 193-201. doi: 10.1016/j.cropro.2012.07.010

Molina Recio, G., Moreno Rojas, R., García Rodríguez, M., and Vaquero Abellán, M. (2016). Nutritional assessment of the most frequently consumed dishes in a slum in Iquitos, Peruvian Amazon. Nut. Hospital. 33, 70-79. doi: $10.20960 / \mathrm{nh} .21$

Morales, H., and Perfecto, I. (2000). Traditional knowledge and pest maanagement in the Guatemala highlands. Agri. Hum. Val. 17:49-63. doi: $10.1023 / \mathrm{A}: 1007680726231$

Munyuli, T. (2011). Farmers' perceptions of pollinators' importance in coffee production in Uganda. Agric. Sci. 2, 318-333. doi: 10.4236/as.2011.23043

Murad, C. A., and Pearse, J. (2018). Landsat study of deforestation in the Amazon region of Colombia: departments of Caquetá and Putumayo. Remote Sens Apps. Society Environ. 11, 161-171. doi: 10.1016/j.rsase.2018.07.003

Mutamiswa, R., Chidawanyika, F., and Nyamukondiwa, C. (2017). Dominance of spotted stemborer Chilo partellus Swinhoe (Lepidoptera: Crambidae) over indigenous stemborer species in Africa's changing climates: ecological and thermal biology perspectives. Agric. Forest Entomol. 19, 344-356. doi: 10.1111/afe.12217

Nicaragua, K., Pavón, F., and Chavarría, E. (2004). Manejo Integrado de Plagas Guía MIP Del Cultivo de La Yuca. Primera Edn. Managua: Impresion comercial La Prensa.

Okonya, J. S., and Kroschel, J. (2016). Farmers' knowledge and perceptions of potato pests and their management in Uganda. J. Agric. Rural Dev. Trop. Subtrop. 117, 87-97. Available online at: https://cgspace.cgiar.org/bitstream/ handle/10568/72707/79286.pdf? sequence $=1$ \&isAllowed $=y$

Ortiz, R., Nowak, A., Lavado, A., and Parker, L. (2013). Food Security in Amazonia. Report for Global Canopy Programme and International Center for Tropical Agriculture as Part of the Amazonia Security Agenda Project, 89. Available online at: http://segamazonia.org/sites/default/files/press_releases/ food_security_in_amazonia.pdf

Ospina, B., and Ceballos, H. (2002). La Yuca en el Tercer Milenio La Yuca En Lel Tercer Milenio. Cali: CIAT, CLAYUCA, Fenavi.

Parugrug, M. L., and Roxas, A. C. (2008). Insecticidal action of five plants against maize weevil, Sitophilus zeamais Motsch (Coleoptera: Curculionidae). KMITL Sci. Tech. J. 8, 24-38. Available online at: https://li01.tci-thaijo.org/index.php/ cast/article/view/136850

Perozo, J., Fuenmayor, F., and Valles, P. M. (2007). Manejo de insectosplaga en el cultivo de la yuca. INIA Divulga. 10, 52-58. Available online at: https://es.scribd.com/document/141073029/Manejo-de-Insectos-Plaga-enEl-Cultivo-de-La-Yuca

Price, L. L. (2001). Demystifying farmers' entomological and pest management knowledge : a methodology for assesing the impacts on knowledge from IPM-FPS and NES intervensions. Agric. Human Val. 18, 153-176. doi: 10.1023/A:1011163307355

Price, L. L., and Gurung, A. B. (2006). Describing and measuring ethnoentomological knowledge of rice pests: tradition and change among Asian rice farmers. Environ. Dev. Sustain. 8:507-517. doi: 10.1007/s10668-006-9052-5

Quintero, M., Vanegas, M., Perez, L., Camilo, K., Gisella, C. S., Sachet, E., et al. (2019). Sustainable Amazonian landcapes, Peru Socioeconomic Survey. CIAT Res. doi: 10.7910/DVN/GTAUFO

R Studio Team (2015). RStudio: Integrated Development for R. Boston, MA: RStudio, Inc. Available online at: http://www.rstudio.com/

Sánchez-Bayo, F., and Wyckhuys, K. A. G. (2019). Worldwide decline of the entomofauna: a review of its drivers. Biol. Conserv. 232, 8-27. doi: 10.1016/j.biocon.2019.01.020

Schweiger, O., Biesmeijer, J. C., Bommarco, R., Hickler, T., Hulme, P. E., Klotz, S., et al. (2010). Multiple stressors on biotic interactions: how climate change and alien species interact to affect pollination. Biol. Rev. Camb. Philos. Soc. 85, 777-795. doi: 10.1111/j.1469-185X.2010.00125.x

Skinner, H. (1930). The giant moth borer of sugar cane (Castnialicus, Drury). Trop. Agric. 7:8.

Sunderland, T., Achdiawan, R., Angelsen, A., Babigumira, R., Ickowitz, A., Paumgarten, F., et al. (2014). Challenging perceptions about men, women, and forest product use: a global comparative study. World Dev. 64, S56-S66. doi: 10.1016/j.worlddev.2014.03.003

Sutrop, U. (2001). List task and a cognitive salience index. Field Methods 13, 263-276. doi: 10.1177/1525822X0101300303

Terra-i (2017). Drone Monitoring of Land Cover Changes Detected by Terra-i in Yurimaguas. Available online at: http://www.terra-i.org/news/news/Dronemonitoring-of-land-cover-changes-detected-by-Terra-I-in-YurimaguasPeru.html

Toledo, V. M. (2002). "Ethnoecology: a conceptual framework for the study of indigenous knowledge of nature," in Ethnobiology and Biocultural Diversity: Proceedings of the 7th International Congress of Ethnobiology (Athens), 511-522.

Toledo, V. M., Toledo, V., Toledo, V., and Toledo, O. M. S. (1992). What is ethnoecology? Origin, scope and implications of a rising discipline. Etnoecol. $1,5-21$.

van der Sluijs, J. P., and Vaage, N. S. (2016). Pollinators and global food security: the need for holistic global stewardship. Food Ethics 1, 75-91. doi: $10.1007 / \mathrm{s} 41055-016-0003-\mathrm{z}$

Vanegas, E. (2018). Plan de Manejo Integrado de La Hormiga Arriera en El Municipio de Campohermoso Boyacá. Campohermoso. Available online at: http://campohermosoboyaca.micolombiadigital.gov.co/sites/ campohermosoboyaca/content/files/000072/3596_hormiga-arriera-encampohermoso.pdf

Vela Panduro, C. R., and Marca, J. V. (2007). Manejo Integrado Del Cultivo de Plátano. Lima: Ministerio de Agricultura (Peru); Instituto Nacional De Investigación Agraria - INIA.

Verma, M., Sharma, S., and Prasad, R. (2009). Biological alternatives for termite control: a review. Int. Biodeter. Biodegrad. 63, 959-972. doi: 10.1016/j.ibiod.2009.05.009

Westbrook, J. K., Nagoshi, R. N., Meagher, R. L., Fleischer, S. J., and Jairam, S. (2016). Modeling seasonal migration of fall armyworm moths. Int. J. Biometeor. 60, 255-267. doi: 10.1007/s00484-015-1022-x

Westermann, O., Ashby, J., and Pretty, J. (2005). Gender and social capital: the importance of gender differences for the maturity and effectiveness of natural resource management groups. World Dev. 33, 1783-1799. doi: 10.1016/j.worlddev.2005. 04.018

Wetzel, A., Casagrande, M., Celette, F., Vian, J. F., Ferrer, A., and Peigné, J. (2013). Agroecological practices for sustainable agriculture. a review. Agron. Sus. Dev. 34, 1-20.

Wetzel, W. C., Kharouba, H. M., Robinson, M., Holyoak, M., and Karban R. (2016). Variability in plant nutrients reduces insect herbivore performance. Nature 539, 425-427. Available online at: https://www.nature.com/articles/nature20140

Wyckhuys, K. A. G., Heong, K. L., Sanchez-Bayo, F., Bianchi, F., Lundgren, J., and Bentley, J. (2019). Ecological illiteracy can deepen farmers' pesticide dependency. PeerJ Preprints 7, e27579-e27571. doi: 10.7287/peerj.preprints. 27579

Wyckhuys, K. A. G., and O’Neil, R. J. (2007). Local agro-ecological knowledge and its relationship to farmers' pest management decision making in rural Honduras. Agric. Human Values 24, 307-321. doi: 10.1007/s10460-0079068-y

Conflict of Interest: The authors declare that the research was conducted in the absence of any commercial or financial relationships that could be construed as a potential conflict of interest.

Copyright (c) 2020 Beltrán-Tolosa, Cruz-Garcia, Solis and Quintero. This is an openaccess article distributed under the terms of the Creative Commons Attribution License (CC BY). The use, distribution or reproduction in other forums is permitted, provided the original author(s) and the copyright owner(s) are credited and that the original publication in this journal is cited, in accordance with accepted academic practice. No use, distribution or reproduction is permitted which does not comply with these terms. 